\title{
Deletion of PPAR- $\gamma$ in immune cells enhances susceptibility to antiglomerular basement membrane disease
}

\author{
Cristen Chafin ${ }^{2}$ \\ Sarah Muse ${ }^{2}$ \\ Raquel Hontecillas ${ }^{5}$ \\ Josep Bassaganya-Riera ${ }^{5}$ \\ David L Caudell ${ }^{2}$ \\ Samuel K Shimp III \\ $M$ Nichole Rylander ${ }^{4}$ \\ John Zhang' \\ Liwu $\mathrm{Li}^{3}$ \\ Christopher M Reilly',2 \\ 'Virginia College of Osteopathic \\ Medicine, ${ }^{2}$ Department of Biomedical \\ Sciences and Pathobiology, Virginia- \\ Maryland Regional College of \\ Veterinary Medicine, Virginia \\ Polytechnic Institute and State \\ University, Blacksburg, VA, USA; \\ ${ }^{3}$ Department of Biological Sciences, \\ ${ }^{4}$ Department of Mechanical \\ Engineering, Virginia Polytechnic \\ Institute and State University, \\ Blacksburg, VA, USA; ${ }^{5}$ Nutritional \\ Immunology and Molecular Medicine \\ Laboratory, Virginia Bioinformatics \\ Institute, Virginia Polytechnic Institute \\ and State University, Blacksburg, \\ VA, USA; ${ }^{6}$ Medical University of SC, \\ Charleston, SC, USA
}

Correspondence: Christopher M Reilly I 4 I0 Prices Fork Rd, Blacksburg, VA 24060, USA

Tel + I 54023 | 9342

Fax +I 54023 I 3426

Email chreilly@vcom.vt.edu

\author{
This article was published in the following Dove Press journal: \\ Journal of Inflammation Research \\ 22 October 2010 \\ Number of times this article has been viewed
}

Abstract: Activation of the nuclear hormone receptor peroxisome proliferator-activated receptor gamma (PPAR- $\gamma$ ) has been shown to be immunoregulatory in autoimmune diseases by inhibiting production of a number of inflammatory mediators. We investigated whether PPAR $-\gamma$ gene deletion in hematopoietic cells would alter disease pathogenesis in the antiglomerular basement membrane (anti-GBM) mouse model. PPAR- $\gamma^{+/+}$and PPAR- $\gamma^{-/-}$mice were immunized with rabbit antimouse GBM antibodies and lipopolysaccharide and evaluated for two weeks. Although both the PPAR- $\gamma^{+/+}$and PPAR- $\gamma^{-/-}$mice had $\mathrm{IgG}$ deposition in the glomerulus and showed proteinuria two weeks after injection, glomerular and tubulointerstitial disease in PPAR- $\boldsymbol{\gamma}^{-/-}$mice were significantly more severe compared with the PPAR- $\boldsymbol{\gamma}^{+/+}$animals. We observed that the PPAR $-\gamma^{-/}$mice had decreased $\mathrm{CD} 4{ }^{+} \mathrm{CD} 25^{+}$regulatory $\mathrm{T}$ cells and an increased $\mathrm{CD}^{+}: \mathrm{CD}^{+}$ratio as compared with the PPAR- $\gamma^{+/+}$mice, suggesting that PPAR- $\gamma$ has a role in the regulation of T cells. Furthermore, plasma interleukin- 6 levels were significantly increased in the PPAR $-\gamma^{-/-}$mice at two weeks as compared with the PPAR- $\gamma^{+/+}$animals. Taken together, these studies show that the lack of PPAR- $\gamma$ expression enhances inflammatory renal disease in the anti-GBM antibody-induced glomerulonephritis mouse model and suggests targeting PPAR- $\gamma$ may have therapeutic efficacy.

Keywords: PPAR- $\gamma$, antiglomerular basement membrane disease

\section{Introduction}

Antiglomerular basement membrane (anti-GBM) disease is an autoimmune disorder that affects the glomeruli of the kidneys. ${ }^{1}$ In this disease, glomerular capillaries become targets of autoantibodies, or anti-GBM antibodies, which are directed against an antigen normally present in the GBM and alveolar basement membrane. ${ }^{2}$ The GBM antigen that is responsible for this disease is a component of the alpha- 3 chain of Type IV collagen. The resulting clinical syndrome encompasses a spectrum ranging from mild or no renal involvement to rapidly progressive glomerulonephritis. Most patients have both pulmonary and kidney involvement. ${ }^{3}$ Clinically, anti-GBM disease that induces both glomerulonephritis and pulmonary hemorrhage is termed Goodpasture's syndrome. ${ }^{1}$

Lupus nephritis is an immune-mediated disease in which T cells, B cells, and innate immune cells have been shown to have pathogenic roles. In mouse models of spontaneous lupus nephritis, disease takes 6-12 months to manifest, necessitating the development of models that will induce lupus-like disease over a quicker timeframe. One such 
model to study spontaneous lupus nephritis is the experimental anti-GBM mouse. ${ }^{4,5}$ GBM glomerulonephritis, characterized by crescent formation and necrotizing inflammation of the glomerular capillary, is the most severe form of glomerulonephritis. When given anti-GBM antibodies and inflammatory stimulation, these animals develop glomerular basement nephritis that in many ways resembles lupus nephritis and Goodpasture's disease. The studies of spontaneous lupus nephritis in mouse models and experimental anti-GBM disease have provided valuable insights into the underlying mechanisms of human lupus nephritis. ${ }^{4,6}$

Peroxisome proliferator-activated receptors (PPARs) belong to the 48-member superfamily of nuclear receptor proteins that function as transcription factors, regulating gene expression. PPARs are receptors for endogenous lipid molecules and are the molecular targets for drugs against Type 2 diabetes. ${ }^{7,8}$ They represent promising new targets for the treatment and prevention of inflammatory and autoimmune disorders, such as inflammatory bowel disease and systemic lupus erythematosus. ${ }^{9-11}$ Treatment with rosiglitazone, a pharmacologic agonist for PPAR- $\gamma$ of the thiazolidinedione class of insulin-sensitizing drugs, has therapeutic efficacy: it reduces autoantibody production, atherosclerosis, and renal injury in lupus nephritis mice, showing reduced glomerular scarring and reduced inflammation in the renal cortex. ${ }^{12,13}$ There are three known PPARs $(\alpha, \beta$, and $\gamma$ ) that each differ in their tissue distribution and functional activity. ${ }^{14}$ PPAR- $\gamma$ is expressed in T and B cells, monocytes/macrophages, dendritic cells, and epithelial cells. ${ }^{15,16}$ There are three isoforms of PPAR $-\gamma ;{ }^{17}$ the first and third are identical when fully translated and only differ in their splice variants, whereas the second differs from the other isoforms at the N-terminus. ${ }^{18}$ All three isoforms have been identified in adipocytes. Additionally, PPAR- $\gamma 1$ is present in virtually all other tissues, including smooth muscle and splenic tissue. PPAR- $\gamma 3$ is expressed in macrophages and in the colon. ${ }^{19}$

Whole body deletion of PPAR- $\gamma$ causes embryonic lethality, but several conditional knockout mouse models have been developed using homozygous floxed PPAR- $\gamma$ mice that result in epithelial and hematopoietic cells lacking PPAR$\gamma \cdot{ }^{20-23}$ PPAR- $\gamma$ conditional knockout peritoneal macrophages have markedly reduced expression of ABCG1, reduced cholesterol efflux, and more atherosclerosis when crossed to a proatherogenic mouse model, such as a low-density lipoprotein receptor knockout. ${ }^{19}$ In our current studies, we sought to determine if the deletion of PPAR- $\gamma$ from hematopoietic cells would result in more severe development of disease in the anti-GBM mouse model, given the anti-inflammatory and immunomodulatory effects of PPAR- $\gamma$ expressed in immune cells.

\section{Materials and methods Mice}

In this project we used PPAR- $\gamma$ floxed mice expressing the Cre transgene ((PPAR- $\gamma$ fl/fl; MMTV-Cre ${ }^{+}$or PPAR- $\gamma^{-/}$) and PPAR- $\gamma$ fl/fl; MMTV-Cre ${ }^{-}$littermate mice $\left(\right.$PPAR- $\left.\gamma^{+/+}\right)$. These mice undergo premature termination of translation due to the enzymatic activity of recombinase in genomic DNA on hematopoietic and epithelial cells. ${ }^{20,24,25}$ We have previously used these mice to cause conditional deletion of PPAR- $\gamma$ in mouse models of irritable bowel disease, obesity and diabetes, and inflammation-driven colorectal cancer. ${ }^{25-28}$ All experimental procedures were approved by the Institutional Animal Care and Use Committee of Virginia Polytechnic Institute and State University, and met or exceeded requirements of the Public Health Service/ National Institutes of Health and the United Stated Animal Welfare Act as amended.

\section{Anti-GBM sera}

Anti-GBM serum was provided by John Zhang (Medical University of South Carolina, Charleston, SC). Essentially, glomeruli from C57BL/6 mice were isolated with a series of grading sieves $(150,106$, and $63 \mu \mathrm{m}$ mesh) and sonicated for seven minutes. Rabbits were next immunized with glomerular sonicates in complete Freund's adjuvant, followed by two injections of antigen in incomplete Freund's adjuvant (2 $\mathrm{mg}$ antigen per rabbit per injection), three weeks apart. Sera harvested from these rabbits seven weeks after the initial injection were tested by direct immunofluorescence to demonstrate strong glomerular binding.

\section{Induction of lupus-like disease}

Six- to eight-week-old mice were injected with a single dose of $100 \mu \mathrm{g}$ lipopolysaccharide (Sigma-Aldrich, St Louis, $\mathrm{MO})$ in phosphate-buffered saline intraperitoneally and administered $250 \mu \mathrm{g}$ anti-GBM sera in phosphate-buffered saline intravenously on day 0 to induce disease. At day 14 , the mice were euthanized and the tissues were collected and analyzed for pathology. ${ }^{5}$

\section{Measurement of proteinuria}

As a measure of renal function, urine was collected at days 0,7 , and 14 and tested for proteinuria by a standard semiquantitative test using Bayer Multistix dipsticks (Bayer, Fernwald, Germany). Results were graded according to the 
manufacturer's instructions as negative, trace $(15-20 \mathrm{mg} / \mathrm{dL}$ of albumin $), 1+(30 \mathrm{mg} / \mathrm{dL}), 2+(100 \mathrm{mg} / \mathrm{dL}), 3+(300 \mathrm{mg} / \mathrm{dL})$, or $4+(>500 \mathrm{mg} / \mathrm{dL})$.

\section{Cytokine enzyme-linked immunosorbent assay}

Interleukin-6 (IL-6) levels in the sera were quantified by an enzyme-linked immunosorbent assay according to the manufacturer's instructions (R\&D Systems Inc., Minneapolis, MN, USA).

\section{Flow cytometric analysis}

Flow cytometric analysis was performed using various combinations of antibodies, including fluorescein isothiocyanate (FITC)-conjugated CD44, R-phycoerythrin-conjugated CD4, FITC-conjugated CD8, and PerCP-CY5.5-conjugated CD25 rat antimouse monoclonal antibodies (BD Pharmingen, San Diego, CA). Splenic cells were isolated as previously described. ${ }^{29}$ Briefly, spleen lymphocytes from PPAR $-\gamma^{+/+}$and PPAR $-\gamma^{-/-}$mice were aseptically dissociated, treated with Tris-ammonium chloride lysis buffer $(\mathrm{pH}$ 7.2) to remove erythrocytes, washed, and placed in complete medium consisting of $10 \%$ heat-inactivated fetal bovine serum, $200 \mathrm{mM}$ L-glutamine, $5000 \mathrm{IU} / \mathrm{mL}$ penicillin, $5000 \mu \mathrm{g} / \mathrm{mL}$ streptomycin, and $100 \times$ nonessential amino acids. Cell numbers were adjusted to $5 \times 10^{6}$ cells $/ \mathrm{mL}$, stained with monoclonal antibodies or appropriate fluorochrome-tagged isotype antirat $\mathrm{IgG}_{2 \mathrm{a}}$ control antibodies, and analyzed on a Coulter Epics XL/MXL flow cytometer (Hialeah, FL).

\section{Kidney pathology}

As we previously described, renal pathology was assessed by a veterinary pathologist who was blinded to the treatment groups. ${ }^{30}$ At day 14, the mice were euthanized for pathologic evaluation. At the time of euthanasia, the mice were weighed and the kidneys were removed and divided into sections. One portion was placed in neutral buffered formalin for subsequent embedding in paraffin, sectioning, and hematoxilyn and eosin and periodic acid-Schiff staining. Sections were assessed via light microscopy for glomerular proliferation, glomerular inflammation, glomerular size, number of nuclei per glomerulus, crescents, necrosis, and fibrosis. Each of these parameters was graded as 0 (normal), 1 (mild increase in mesangial matrix and cellularity), 2 (moderate increase in mesangial matrix and cellularity), 3 (focal endocapillary hypercellularity, obliterated capillary lumen, and marked thickening of glomerular basement membrane), or 4 (crescent formation, segmental necrosis, marked hypercellularity, and hyalinized glomeruli), and an overall glomerular score was derived. ${ }^{31}$ One portion of the kidney was frozen in optimal cutting temperature media and cut into $5 \mu \mathrm{m}$ sections and stained with FITC-conjugated antibodies (goat antimouse IgG diluted 1:100, Pierce, Rockford, IL).

\section{Statistical analysis}

Statistical analysis was performed by Student's $t$-test. A $P$ value $<0.05$ was considered statistically significant.

\section{Results}

\section{Rabbit IgG deposition in kidneys after anti-GBM antibody injection}

Before assessing the impact of PPAR $-\gamma$ gene deletion on susceptibility to immune-mediated glomerular basement nephritis, we first sought to determine if the kidneys from the PPAR- $\gamma^{+/+}$ and PPAR- $\gamma^{-/-}$mice showed similar glomerular staining patterns to anti-GBM treatment. Fourteen days after the induction of disease, the anti-GBM antibodies were observed to bind exclusively to the glomerular capillary wall in a linear pattern (Figure 1). Additionally, the kidneys from both the PPAR- $\gamma^{+/+}$ and PPAR $-\gamma^{-/-}$mice showed similar amounts of rabbit antimouse IgG antibodies in their glomeruli.

\section{Determination of proteinuria}

Prior to the induction of disease (day 0), both the PPAR- $\gamma^{+/+}$and PPAR $-\gamma^{-/-}$mice showed minimal proteinuria (Figure 2 ). At day 14, both the PPAR $-\gamma^{+/+}$and PPAR $-\gamma^{-/-}$animals had significantly greater amounts of proteinuria by dipstick analysis compared with the baseline. The differences were not statistically significant between the PPAR- $\gamma^{+/+}$and PPAR- $\gamma^{-/-}$mice at day 14 .

\section{Effect of anti-GBM sera on splenic tissue}

At day 14, the animals were sacrificed and the spleen weights were measured. The spleen weights and spleen to body weights were not statistically different between PPAR- $\gamma^{+/+}$and PPAR $-\gamma^{-/-}$mice $(0.056 \pm 0.14 \mathrm{~g}$ versus $0.054 \pm 0.014 \mathrm{~g}$ for spleen and $22.5 \pm 2.3$ g versus $23.4 \pm 3.2$ g body weight, respectively).
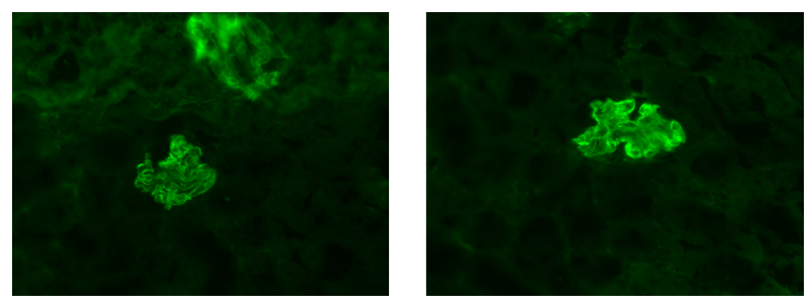

Figure I Representative picture of IgG staining in the glomerulus at DI4. Renal deposition of anti-GBM antibodies between PPAR- $\gamma^{+/+}$(right) and PPAR- $\gamma^{-1-}$ mice (left). Abbreviations: GBM, glomerular basement membrane; PPAR- $\gamma$, peroxisome proliferator-activated receptor gamma. 


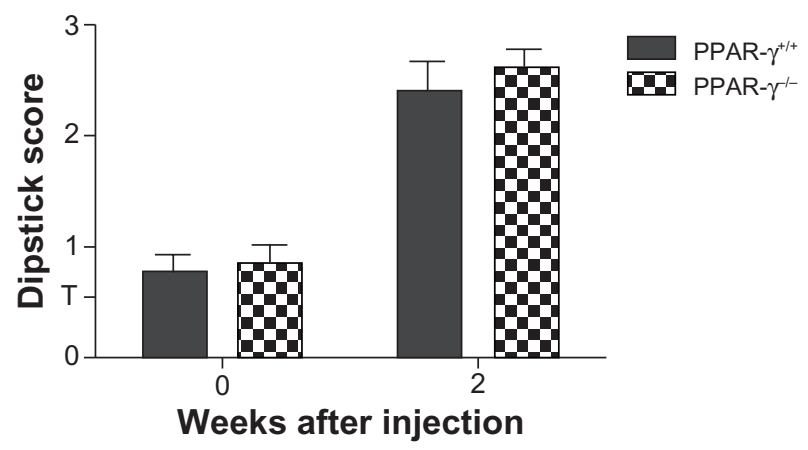

Figure 2 Proteinuria measured by dipstick analysis in PPAR- $\gamma^{+/+}$and PPAR- $\gamma^{-/-}$mice. There was no significant difference between the groups $(n=10)$. Abbreviation: PPAR- $\gamma$, peroxisome proliferator-activated receptor gamma.

To characterize the splenic phenotype, we isolated the dissociated splenocytes. There was no difference in total splenocyte numbers between the PPAR $-\gamma^{+/+}$and PPAR- $\gamma^{-/-}$mice (data not shown). Next, we assessed the $T$ cell populations by flow cytometry. We examined the $\mathrm{CD}^{+}: \mathrm{CD}^{+}$ratio, $\mathrm{CD} 4^{+} \mathrm{CD} 25^{+}$ ( $\mathrm{T}$ regulatory cells), and $\mathrm{CD} 4^{+} \mathrm{CD} 44^{+}$(activated memory $\mathrm{T}$ cells) due to prior reports showing PPAR- $\gamma$ expression or activation modulates $\mathrm{T}$ cell profiles by altering the $\mathrm{CD} 4^{+}: \mathrm{CD}^{+}$ratio and the $\mathrm{T}$ regulatory cell population. ${ }^{32,33}$ Our results showed that there was no difference in the $\mathrm{CD} 4^{+} \mathrm{CD} 44^{+}$expression profiles in PPAR- $\gamma^{+/+}$mice compared with PPAR- $\gamma^{-/}$mice. Intriguingly, we found that the PPAR $-\gamma^{-/}$mice exhibited a significant decrease in the $\mathrm{CD}^{+}: \mathrm{CD}^{+} \mathrm{T}$ cell ratio, as well as a decrease in $\mathrm{CD} 4^{+} \mathrm{CD} 25^{+}$cells compared with the PPAR- $\gamma^{+/+}$ mice (Figure 3 and Table 1).

\section{Kidney pathology}

Both PPAR- $\gamma^{+/+}$and PPAR- $\gamma^{-/-}$mice developed renal disease with anti-GBM antibody administration characterized by relatively mild glomerular inflammation. However, the PPAR $-\gamma^{-/}$mice showed significantly more severe disease compared with the PPAR $-\gamma^{+/+}$mice (Figure 4). In addition to increased glomerular inflammation, the PPAR- $\gamma^{-/-}$mice had increased mesangial matrix that obliterated the glomerular architecture (as shown in the periodic acid-Schiff-stained sections of the kidney). Furthermore, several of the PPAR- $\gamma^{-/-}$ mice showed severe interstitial abnormalities.

\section{Evaluation of cytokine levels}

We measured serum levels of the proinflammatory cytokine IL-6 as a measure of inflammation (Figure 5). Prior to induction of anti-GBM disease, IL-6 levels were not detectable. Two weeks after anti-GBM antibody administration, IL-6 levels in the PPAR- $\gamma^{-/-}$mice were significantly elevated compared with PPAR- $\gamma^{+/+}$mice.

\section{Discussion}

The activation of PPAR- $\gamma$ was originally shown to block the proinflammatory effects of lipopolysaccharide and various cytokines in both monocytes and macrophages by antagonizing the activities of AP-1, STAT, and NF- $\kappa B^{34,35}$ Specifically, activation of PPAR- $\gamma$ decreased the production of nitric oxide, IL-6, and tumor necrosis factor-alpha. Since these initial observations, numerous studies have further characterized the expression, regulation, and mechanism of PPAR- $\gamma$ 's anti-inflammatory activity.

In our current studies, we sought to determine the effects of PPAR- $\gamma$ gene deletion in hematopoietic and epithelial cells using a mouse model of induced glomerulonephritis. The administration of anti-GBM antibodies and lipopolysaccharide stimulation serves as an acceptable model for murine glomerulonephritis with characteristics of Goodpasture's syndrome as well as lupus nephritis. ${ }^{4,36}$ Our studies demonstrate that PPAR- $\gamma$ has a role in the maintenance of regulatory $\mathrm{T}$ cell numbers. We found that PPAR- $\gamma$ gene deletion resulted in a decreased $\mathrm{CD} 4{ }^{+} \mathrm{CD} 25^{+} \mathrm{T}$ cell population, along with an increase in disease in mice challenged with lipopolysaccharide and anti-GBM antibodies. This coincides with previous reports demonstrating that the deletion of PPAR- $\gamma$ in $\mathrm{T}$ regulatory cells abrogates their ability to prevent $\mathrm{CD}^{+}$ T cell-induced colitis in adoptive transfer studies and ameliorate graft versus host disease. ${ }^{26,33}$ We have previously shown the importance of $\mathrm{T}$ regulatory cells in decreasing disease severity in lupus mice. ${ }^{37}$ Together, these studies indicate that a decrease in T regulatory cell numbers and/or function contributes to the development of autoimmune diseases.

Several lines of evidence suggest that PPAR- $\gamma$ exerts anti-inflammatory effects by negatively regulating the expression of proinflammatory genes induced during macrophage differentiation/activation and the production of proinflammatory cytokines. ${ }^{38}$ We observed a significant increase in the production of Th1/Th17 cytokine IL- 6 after PPAR- $\gamma$ gene deletion. IL-6 is not only important for the differentiation of Th1/Th17 phenotypes, but is also critical for inhibiting the differentiation of T regulatory cells. ${ }^{39}$ This is consistent with our flow cytometry analyses showing a decreased $\mathrm{T}$ regulatory cell population of mice deficient in PPAR- $\gamma$. The general skewing of immune cell phenotypes may play a significant role during the pathogenesis of renal nephritis and lupus in mice and humans. Moreover, the deletion of PPAR- $\gamma$ in $\mathrm{CD}^{+}$ $T$ cells results in enhanced antigen-specific proliferation and overproduction of interferon- $\gamma$ in response to IL-12, indicating that adequate expression of PPAR- $\gamma$ in $\mathrm{CD}^{+} \mathrm{T}$ cells is required to downregulate excessive Th1 responses. ${ }^{26}$ 

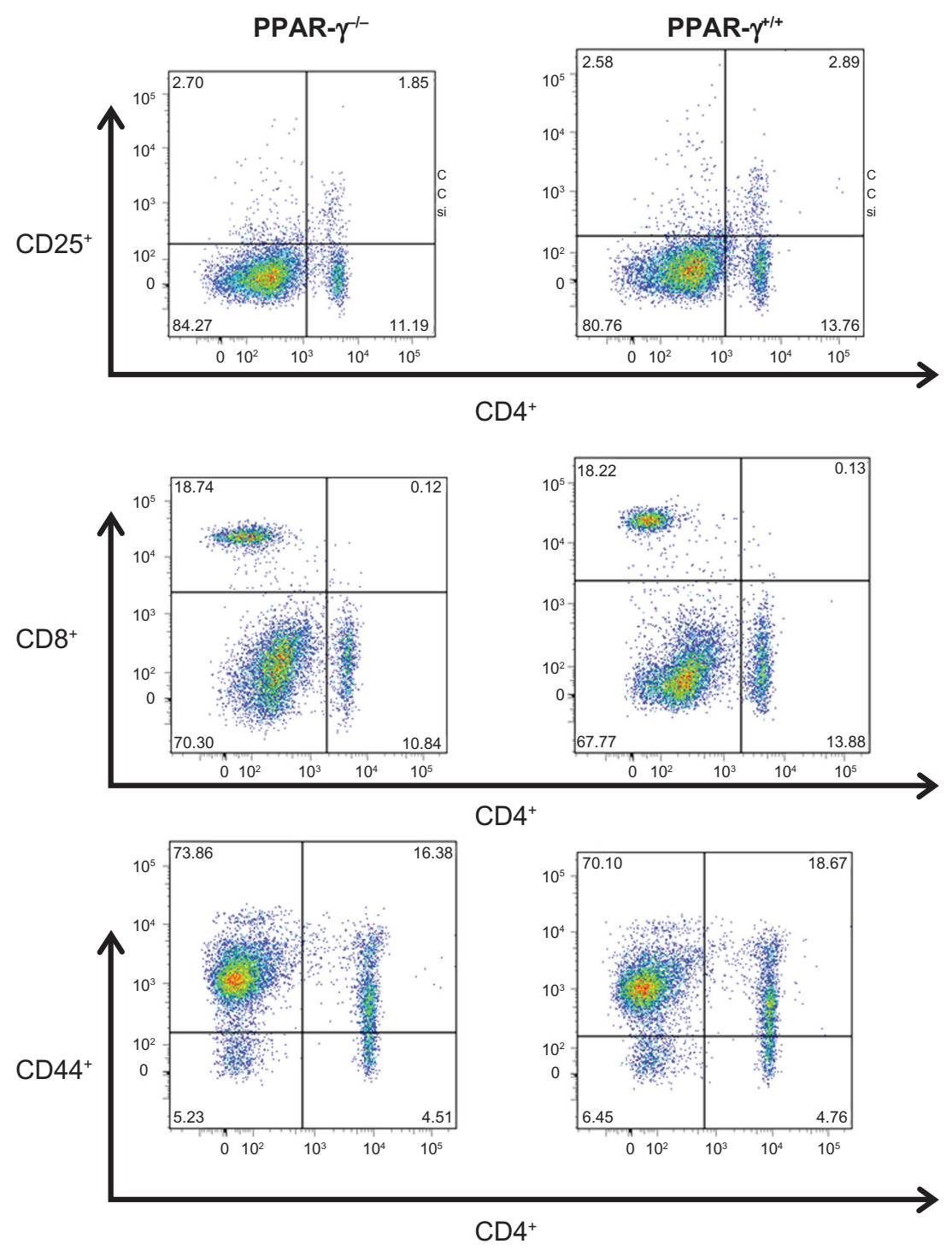

Figure 3 Representative histograms of flow cytometric staining of freshly isolated splenocytes from PPAR- $\gamma^{+1+}$ and PPAR- $\gamma^{--}$mice I4 days after stimulation with anti-GBM sera/LPS administration.

Abbreviations: GBM, glomerular basement membrane; PPAR- $\gamma$, peroxisome proliferator-activated receptor gamma; LPS, lipopolysaccharide.

Perhaps the most striking difference we observed in the PPAR- $\boldsymbol{\gamma}^{-/-}$mice was the more severe development of glomerular and interstitial lesions compared with the PPAR- $\gamma^{+/+}$ mice, demonstrating the role for PPAR- $\gamma$ gene expression in modulating renal disease. Direct binding of antiglomerular antibodies to glomerular antigens plays a key role in disease pathogenesis in the GBM model. All specimens of the anti-
GBM antibody-treated mice showed linear deposition of $\operatorname{IgG}$ along the GBM accompanied by complement $\mathrm{C} 3$ deposits. Our observations by light microscopy revealed a significant overall increase in glomerular pathology, including crescent formation in the PPAR- $\gamma^{-/-}$mice, while the PPAR- $\gamma^{+/+}$mice showed less pathology. Interestingly, we found that proteinuria was similar in both the PPAR- $\gamma^{-/-}$and PPAR- $\gamma^{+/+}$mice.

Table I Percentage of T cell markers in the spleens of mice with autoimmune anti-GBM glomerulonephritis $(n=10)$

\begin{tabular}{llllll}
\hline Parameter & CD4 $^{+}$T cells & CD8 $^{+}$T cells & CD8 $^{+}:$CD4 $^{+}$ratio & CD4 $^{+}$CD44 $^{+}$cells & CD4 $^{+}$CD25 $^{+}$cells \\
\hline PPAR- $\gamma^{+/+}$ & $13.95 \pm 0.4+$ & $15.86 \pm 2.6$ & $1.16 \pm 0.08$ & $17.62 \pm 2.8$ & $2.84 \pm 0.31$ \\
PPAR- $\gamma^{\prime-}$ & $10.98 \pm 0.3$ & $14.95 \pm 2.4$ & $1.36 \pm 0.13^{*}$ & $17.17 \pm 3.4$ & $1.96 \pm 0.28^{*}$ \\
\hline
\end{tabular}

$* P<0.05$.

Abbreviations: GBM, glomerular basement membrane; PPAR- $\gamma$, peroxisome proliferator-activated receptor gamma. 
A
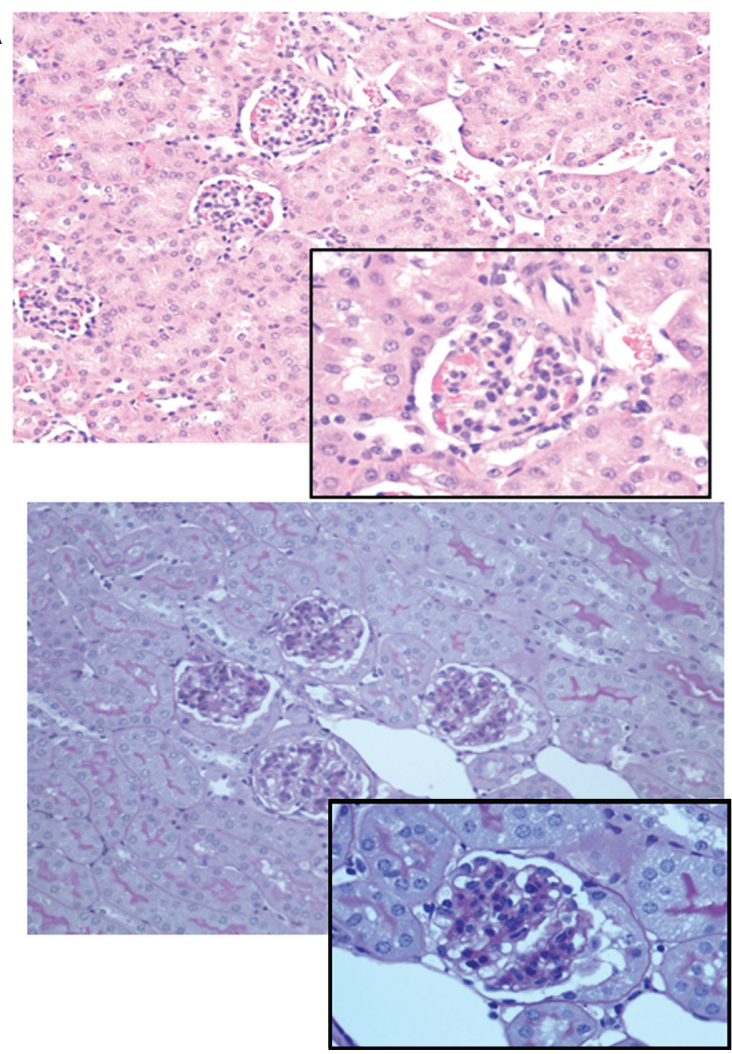

B

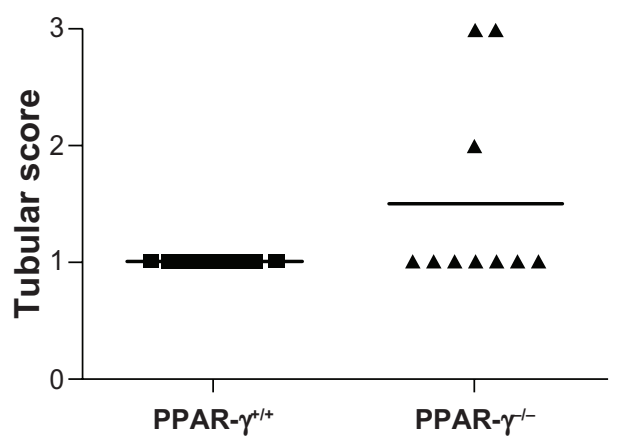

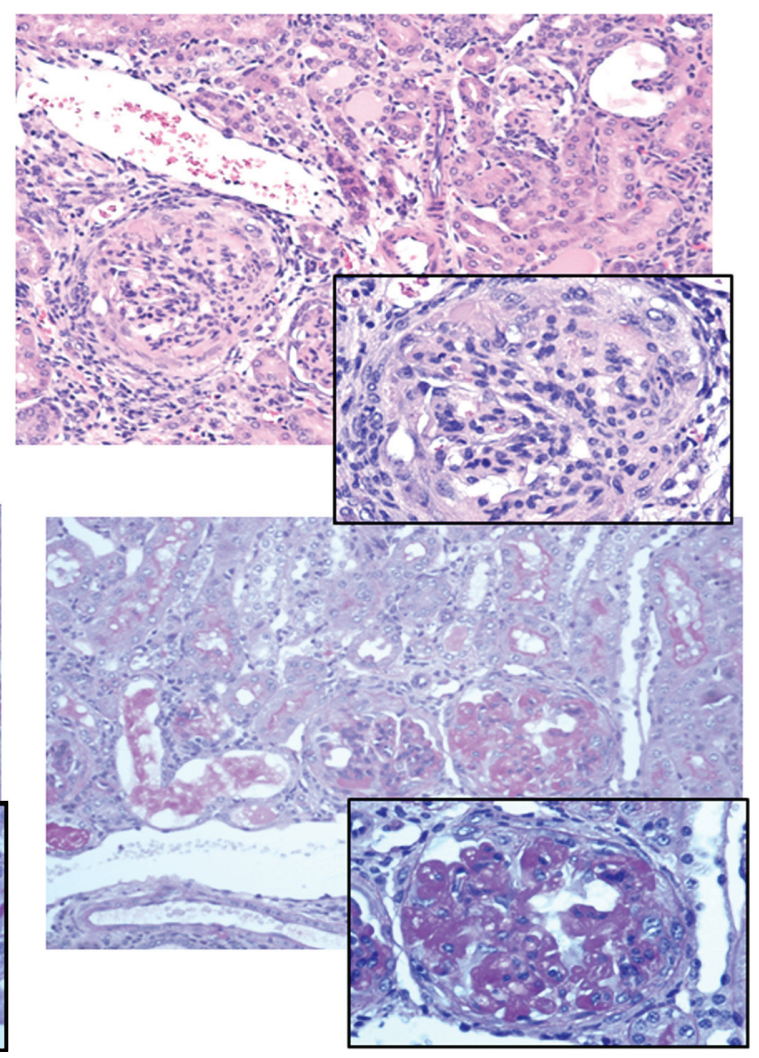

C

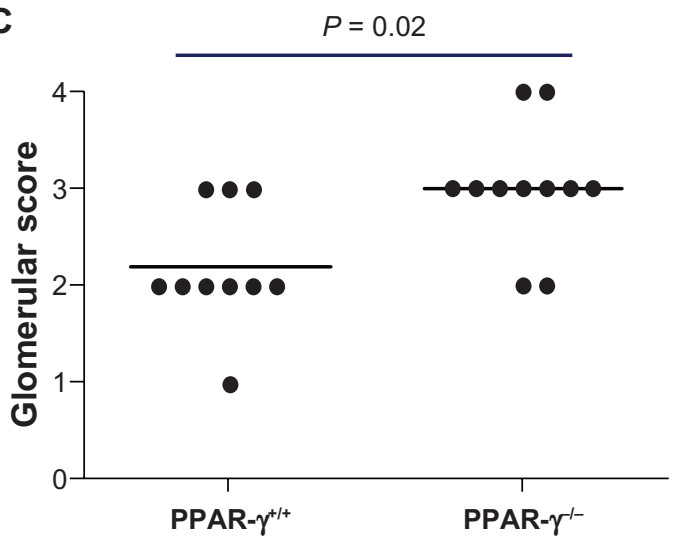

Figure 4 Renal pathology of PPAR- $\gamma^{+/+}$and PPAR- $\gamma^{-1-}$ two weeks after anti-GBM administration. A Representative photomicrograph of a kidney from a PPAR- $\gamma^{+/+}$(upper left) and PPAR- $\gamma^{--}$(upper right) with hematoxylin and eosin stain (insert $25 \times$ magnification of glomeruli). Note the severe cellular infiltrate and crescent formation in the PPAR- $\gamma^{-1-}$ mouse kidney. Representative photomicrograph of a kidney from a PPAR- $\gamma^{+/+}$(lower left) and PPAR- $\gamma^{-1-}$ (lower right) with periodic acid-Schiff stain. Note the increased deposition of periodic acid-Schiff-positive mesangial matrix in the PPAR- $\gamma^{-1-}$ mouse kidney. B Tabulation of renal tubular and $\mathbf{C}$ glomerular interstitium. Abbreviations: GBM, glomerular basement membrane; PPAR- $\gamma$, peroxisome proliferator-activated receptor gamma.

This finding could be due to the single time point at which we collected urine and our method of determination of proteinuria. A 24-hour urine collection may have shown a better representation of urine output with respect to proteinuria.

In lupus nephritis mouse models, PPAR- $\gamma$ activation has shown therapeutic effects, leading to the reduction of disease. Recently Venegas-Pont et al reported that PPAR- $\gamma$ agonists showed beneficial effects on renal function in the
NZB/W lupus mouse. ${ }^{12}$ Others have suggested that PPAR- $\gamma$ modulates renal disease in lupus nephritis through induction of adiponectin. ${ }^{13}$ These studies support our findings for a therapeutic benefit of PPAR- $\gamma$ in autoimmune nephritis. We have previously demonstrated that mesangial cells produce endogenous PPAR- $\gamma$ ligands. ${ }^{40}$ The results presented in this paper are in line with the effect of endogenous PPAR- $\gamma$ ligands on PPAR- $\gamma$ expressed in immune cells, because the 


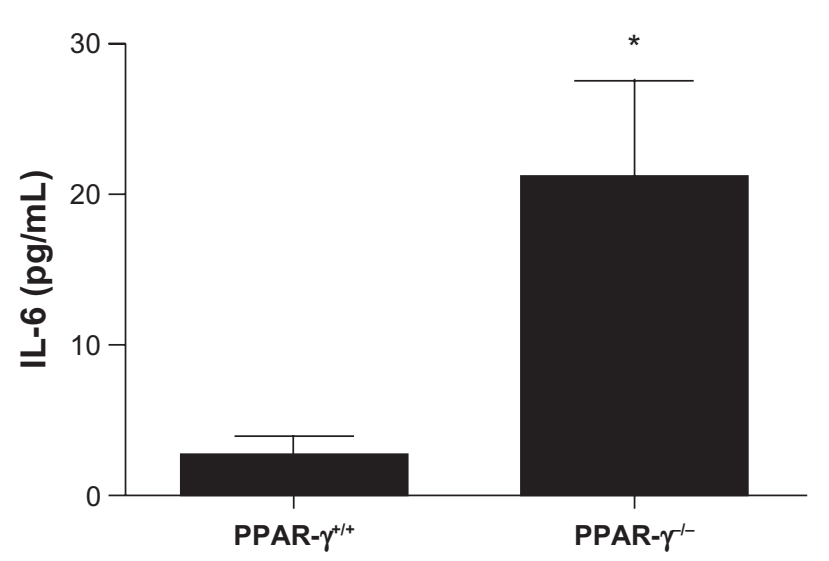

Figure 5 Serum interleukin- 6 levels in PPAR- $\gamma^{+/+}$and PPAR- $\gamma^{-1-}$ mice with induction of anti-GBM disease. Sera were assayed by enzyme-linked immunosorbent assayl 4 days after induction of disease. The levels of interleukin- 6 in the PPAR- $\gamma^{-1-}$ mice were significantly greater compared with the PPAR- $\gamma^{+/+}$mice $(n=10)$. $* p<0.05$.

Abbreviations: GBM, glomerular basement membrane; PPAR- $\gamma$, peroxisome proliferator-activated receptor gamma.

deletion of PPAR- $\gamma$ resulted in increased kidney pathology in autoimmune mice. Additionally, endogenously generated lipid molecules can also activate PPAR- $\gamma$, suggesting pharmacologic or dietary intervention may not be required for PPAR- $\gamma$ modulation of disease. ${ }^{41,42}$ Taken together, these observations support a critical role for PPAR- $\gamma$ expression in the maintenance of kidney homeostasis and support the notion that PPAR- $\gamma$ may be a therapeutic avenue to target for inhibition of autoimmune inflammatory kidney diseases.

\section{Disclosure}

The authors report no conflicts of interest in this work.

\section{References}

1. Abbate M, Kalluri R, Corna D, et al. Experimental Goodpasture's syndrome in Wistar-Kyoto rats immunized with alpha3 chain of type IV collagen. Kidney Int. 1998;54:1550-1561.

2. Kettritz R. Autoimmunity in kidney diseases. Scand J Clin Lab Invest Suppl. 2008;241:99-103.

3. Bosch X, Font J. The pulmonary-renal syndrome: A poorly understood clinicopathologic condition. Lupus. 1999;8:258-262.

4. Du Y, Fu Y, Mohan C. Experimental anti-GBM nephritis as an analytical tool for studying spontaneous lupus nephritis. Arch Immunol Ther Exp (Warsz). 2008;56:31-40.

5. Xie C, Rahman ZS, Xie S, et al. Strain distribution pattern of immune nephritis - a follow-up study. Int Immunol. 2008;20:719-728.

6. Li QZ, Zhou J, Yang R, et al. The lupus-susceptibility gene kallikrein downmodulates antibody-mediated glomerulonephritis. Genes Immun. 2009; 10:503-508.

7. Desvergne B, Wahli W. Peroxisome proliferator-activated receptors: Nuclear control of metabolism. Endocr Rev. 1999;20:649-688.

8. Nesto RW, Bell D, Bonow RO, et al. Thiazolidinedione use, fluid retention, and congestive heart failure: A consensus statement from the American Heart Association and American Diabetes Association. Oct 7, 2003. Circulation. 2003;108:2941-2948.

9. Yang M, Pariza MW, Cook ME. Dietary conjugated linoleic acid protects against end stage disease of systemic lupus erythematosus in the NZB/W F1 mouse. Immunopharmacol Immunotoxicol. 2000;22: 433-449.
10. Yang XY, Wang LH, Chen T, et al. Activation of human T lymphocytes is inhibited by peroxisome proliferator-activated receptor gamma (PPARgamma) agonists. PPARgamma co-association with transcription factor NFAT. J Biol Chem. 2000;275:4541-4544.

11. Bergamo P, Luongo D, Maurano F, Mazzarella G, Stefanile R, Rossi M. Conjugated linoleic acid enhances glutathione synthesis and attenuates pathological signs in MRL/MpJ-Fas(lpr) mice. J Lipid Res. 2006;47:2382-2391.

12. Venegas-Pont M, Sartori-Valinotti JC, Maric C, et al. Rosiglitazone decreases blood pressure and renal injury in a female mouse model of systemic lupus erythematosus. Am J Physiol Regul Integr Comp Physiol. 2009;296:R1282-R1289.

13. Aprahamian T, Bonegio RG, Richez C, et al. The peroxisome proliferator-activated receptor gamma agonist rosiglitazone ameliorates murine lupus by induction of adiponectin. J Immunol. 2009;182:340-346.

14. Mangelsdorf DJ, Evans RM. The RXR heterodimers and orphan receptors. Cell. 1995;83:841-850.

15. Spiegelman BM. PPAR gamma in monocytes: Less pain, any gain? Cell. 1998;93:153-155.

16. Mansen A, Guardiola-Diaz H, Rafter J, Branting C, Gustafsson JA. Expression of the peroxisome proliferator-activated receptor (PPAR) in the mouse colonic mucosa. Biochem Biophys Res Commun. 1996;222:844-851.

17. Schoonjans K, Martin G, Staels B, Auwerx J. Peroxisome proliferatoractivated receptors, orphans with ligands and functions. Curr Opin Lipidol. 1997;8:159-166.

18. Fajas L, Fruchart JC, Auwerx J. PPAR gamma3 mRNA: A distinct PPARgamma mRNA subtype transcribed from an independent promoter. FEBS Lett. 1998;438:55-60.

19. Braissant O, Foufelle F, Scotto C, Dauca M, Wahli W. Differential expression of peroxisome proliferator-activated receptors (PPARs): Tissue distribution of PPAR-alpha, -beta, and -gamma in the adult rat. Endocrinology. 1996;137:354-366.

20. Cui Y, Miyoshi K, Claudio E, et al. Loss of the peroxisome proliferationactivated receptor gamma (PPARgamma) does not affect mammary development and propensity for tumor formation but leads to reduced fertility. J Biol Chem. 2002;277:17830-17835.

21. Adachi M, Kurotani R, Morimura K, et al. Peroxisome proliferator activated receptor gamma in colonic epithelial cells protects against experimental inflammatory bowel disease. Gut. 2006;55:1104-1113.

22. Guri AJ, Mohapatra SK, Horne WT 2nd, Hontecillas R, BassaganyaRiera J. The role of T cell PPAR gamma in mice with experimental inflammatory bowel disease. BMC Gastroenterol. 2010;10:60.

23. Mohapatra SK, Guri AJ, Climent M, et al. Immunoregulatory actions of epithelial cell PPAR gamma at the colonic mucosa of mice with experimental inflammatory bowel disease. PLoS One. 2010;5:e10215.

24. Akiyama TE, Sakai S, Lambert G, et al. Conditional disruption of the peroxisome proliferator-activated receptor gamma gene in mice results in lowered expression of $\mathrm{ABCA} 1, \mathrm{ABCG} 1$, and apoE in macrophages and reduced cholesterol efflux. Mol Cell Biol. 2002;22:2607-2619.

25. Bassaganya-Riera J, Reynolds K, Martino-Catt S, et al. Activation of PPAR gamma and delta by conjugated linoleic acid mediates protection from experimental inflammatory bowel disease. Gastroenterology. 2004;127:777-791.

26. Hontecillas R, Bassaganya-Riera J. Peroxisome proliferator-activated receptor gamma is required for regulatory $\mathrm{CD} 4+\mathrm{T}$ cell-mediated protection against colitis. J Immunol. 2007;178:2940-2949.

27. Guri AJ, Hontecillas R, Ferrer G, et al. Loss of PPAR gamma in immune cells impairs the ability of abscisic acid to improve insulin sensitivity by suppressing monocyte chemoattractant protein-1 expression and macrophage infiltration into white adipose tissue. J Nutr Biochem. 2008;19:216-228.

28. Evans NP, Misyak SA, Schmelz EM, Guri AJ, Hontecillas R, Bassaganya-Riera J. Conjugated linoleic acid ameliorates inflammationinduced colorectal cancer in mice through activation of PPARgamma. J Nutr. 2010;140:515-521. 
29. Ahmed SA, Gogal RM Jr, Walsh JE. A new rapid and simple nonradioactive assay to monitor and determine the proliferation of lymphocytes: An alternative to [3H]thymidine incorporation assay. J Immunol Methods. 1994;170:211-224.

30. Sekine H, Reilly CM, Molano ID, et al. Complement component C3 is not required for full expression of immune complex glomerulonephritis in MRL/lpr mice. J Immunol. 2001;166:6444-6451.

31. Xie C, Sharma R, Wang H, Zhou XJ, Mohan C. Strain distribution pattern of susceptibility to immune-mediated nephritis. J Immunol. 2004; 172:5047-5055.

32. Malur A, McCoy AJ, Arce S, et al. Deletion of PPAR gamma in alveolar macrophages is associated with a Th-1 pulmonary inflammatory response. J Immunol. 2009;182:5816-5822.

33. Wohlfert EA, Nichols FC, Nevius E, Clark RB. Peroxisome proliferatoractivated receptor gamma (PPARgamma) and immunoregulation: Enhancement of regulatory T cells through PPARgamma-dependent and -independent mechanisms. J Immunol. 2007;178:4129-4135.

34. Lavinsky RM, Jepsen K, Heinzel T, et al. Diverse signaling pathways modulate nuclear receptor recruitment of N-CoR and SMRT complexes. Proc Natl Acad Sci U S A. 1998;95:2920-2925.

35. Ricote M, Huang J, Fajas L, et al. Expression of the peroxisome proliferator-activated receptor gamma (PPARgamma) in human atherosclerosis and regulation in macrophages by colony stimulating factors and oxidized low density lipoprotein. Proc Natl Acad Sci USA. 1998;95:7614-7619.
36. Fu Y, Du Y, Mohan C. Experimental anti-GBM disease as a tool for studying spontaneous lupus nephritis. Clin Immunol. 2007;124: 109-118.

37. Reilly CM, Thomas M, Gogal R Jr, et al. The histone deacetylase inhibitor trichostatin A upregulates regulatory $\mathrm{T}$ cells and modulates autoimmunity in NZB/W F1 mice. J Autoimmun. 2008;31: 123-130.

38. Abdelrahman M, Sivarajah A, Thiemermann C. Beneficial effects of PPAR-gamma ligands in ischemia-reperfusion injury, inflammation and shock. Cardiovasc Res. 2005;65:772-781.

39. Wan S, Xia C, Morel L. IL-6 produced by dendritic cells from lupusprone mice inhibits CD4+CD25+T cell regulatory functions. J Immunol. 2007; 178:271-279.

40. Reilly CM, Oates JC, Cook JA, Morrow JD, Halushka PV, Gilkeson GS. Inhibition of mesangial cell nitric oxide in MRL/lpr mice by prostaglandin $\mathrm{J}(2)$ and proliferator activation receptor-gamma agonists. J Immunol. 2000;164:1498-1504.

41. Namgaladze D, Morbitzer D, von Knethen A, Brune B. Phospholipase A2-modified low-density lipoprotein activates macrophage peroxisome proliferator-activated receptors. Arterioscler Thromb Vasc Biol. 2010;30:313-320.

42. Borniquel S, Jansson EA, Cole MP, Freeman BA, Lundberg JO. Nitrated oleic acid up-regulates PPARgamma and attenuates experimental inflammatory bowel disease. Free Radic Biol Med. 2010;48: $499-505$.

\section{Publish your work in this journal}

The Journal of Inflammation Research is an international, peer-reviewed open-access journal that welcomes laboratory and clinical findings on the molecular basis, cell biology and pharmacology of inflammation including original research, reviews, symposium reports, hypothesis formation and commentaries on: acute/chronic inflammation; mediators of inflamma-

\section{Dovepress}

tion; cellular processes; molecular mechanisms; pharmacology and novel anti-inflammatory drugs; clinical conditions involving inflammation. The manuscript management system is completely online and includes a very quick and fair peer-review system. Visit http://www.dovepress.com/ testimonials.php to read real quotes from published authors. 